\title{
EFFECT OF TEMPERATURE AND HOST PLANT ON DVELOPMENTAL TIMES AND LIFE TABLE PRARMETERS OF TETRANYCHUS URTICAE KOCH ON PERSIMMON TREES. (ACARI: TETRANYCHIDAE)
}

\author{
EL-HALAWANY, A.S.H. and N. M. ABD EL-WAHED
}

Dr_ashraf_said@yahoo.com

Plant protection Research Institute, ARC, Dokki, Giza, Egypt.

(Manuscript received 11 November 2012)

\begin{abstract}
The two-spotted spider mite, Tetranychus urticae Koch is one of the most important pests of deciduous fruit trees in Egypt. The reproduction, survival, and life table parameters of $T$. urticae on Kostata and Hachiya Persimmon cultivars leaves were studied under laboratory conditions of $15,20,25$ and $30 \pm 2^{\circ} \mathrm{C}, 70 \pm 5 \%$ $\mathrm{RH}$ and a photoperiod of 16L: 8D. The shortest period of incubation, immature stages and female longevity were $3.27,8.92$ and 12.98 days, while these periods for males were $3.35,7.8$ and 11.8 days at $30^{\circ} \mathrm{C}$ on Kostata persimmon variety, respectively. 30 ${ }^{\circ} \mathrm{C}$ gave the maximum value of intrinsic rate of increase $\left(\mathbf{r}_{\mathbf{m}}\right) 0.243$ and 0.297 individuals/ $q /$ day on and maximum net reproductive rate (Ro) 47.51 and 63.47 individuals/ $q$ on Kostata and Hachiya varieties, respectively. Maximum fecundity was obtained on Kostata variety at $30^{\circ} \mathrm{C}$ at day 15 as 8.93 eggs/o/day. It was concluded that the Hachiya variety was more favorable for $T$. urticae than Kostata variety resulting in the highest fecundity and reproduction at $30^{\circ} \mathrm{C}$.
\end{abstract}

\section{INTRODUCTION}

Tetranychus urticae Koch is the most polyphagous species of spider mites and has been reported from over 150 host plant species of economic value. It attacks over 300 plant species in greenhouses (Zhang (2003)).

This mite causes heavy damages to persimmon orchards at Barrage District, Qaluobia Governorate in Egypt. Symptoms of T. urticae damage are yellowish foliage and, whitish streaks on the stems. The population growth parameters of $T$. urticae such as developmental rate, survival, reproduction and longevity vary with temperature, host phonological stage and relative humidity (Farrag 1975, Kim et. al. 1993, Liu and Tsai 1998 and El-Halawany 2001). Plants have main effects on demographic parameters of spider mite population dynamics. Therefore, in order to develop a successful integrated pest management (IPM) program, it is important to accurately characterize its life-history parameters on diverse host plants (Heikal et. al. 1996, Abdel-Wahed 2003, Ismail 2008, 2009, Riahi et. al. 2011). 
There is the present work aimed to study the effect of temperature and host plant of Persimmon varieties under laboratory conditions.

\section{MATERIALS AND METHODS}

\section{Mite culture}

The initial population of $T$. urticae was collected from persimmon trees (Diospyros virginiana L., Family Ebenaceae) in Barrage District, Qaluobia Governorate. The stock culture was maintained on persimmon leaves in a rearing chamber $(25 \pm$ $2^{\circ} \mathrm{C}, 70 \pm 5 \% \mathrm{RH}$. and 16:8 light (L): dark (D) and kept at Plant Protection Research Institute.

\section{Development and biology of $\boldsymbol{T}$. urticae at different temperatures}

Experiments were conducted on Kostata and Hachiya persimmon varieties leaf discs at $15,20,25$ and $30 \pm 2{ }^{\circ} \mathrm{C}, 70 \pm 5 \% \mathrm{RH}$ and 16:8 L: D photoperiod. One leaflet from the first fully expanding leaf at the top per plant of each variety was chosen. It was well washed with running water to remove any possible residuals or mites. Leaf discs of about $2.5 \mathrm{Cm}$ in diameter were made surrounded by tangle foot, and placed lower surface up on of moisten cotton wool in Petri dishes of $10-\mathrm{cm}$ diameter and a $T$. urticae couple (male and female) was placed on each disc, for each variety. These Petri dishes were kept at four temperatures, for 24 hours to allow mating, thereafter, males were removed, while female served as a source for knownage eggs, and larvae. About 60 hatching larvae were kept singly to a leaf of each variety and left to continue their life span. Newly emerged females were copulated and left to deposit their eggs. Monitor was conducted twice daily and essential records were noted. To determine sex ratio, ten newly emerged females to which males were added placed on leaf discs and kept under the same condition of temperatures and RH. From the deposited eggs of each female, 50 eggs ( 25 eggs after two days and 25 eggs after one week) were left to develop second, and then males and females were counted. This was applied for different temperatures and hosts. Dishes were kept in incubators containing saturated solution of $\mathrm{NaCl}$ to maintain at $7 \% \mathrm{RH}$ according to (Winston and Bates 1960)

\section{Life table parameters of the two-spotted spider mite}

Females of $T$. urticae reached adult stage were transferred singly each to a single female on new leaf discs. Developmental period, mortality of different stages and oviposition by resultant females were recorded daily for each female. Life table parameters were estimated according to (Birch, 1948) using the Life48, BASIC Computer program (Abou-Setta et. al., 1986). 


\section{Statistical analysis}

The relationship between the rate of development $(Y)$ and temperature $(X)$ (at a specific range) can be represented by a straight line resembled with the linear equation $\left(Y=a+b X{ }^{\circ} C\right)$, a (intercept), $b$ (slope of temperature). The threshold temperature for development $\left(t_{0}\right)$ can be estimated using the equation, $a s-a / b$ (i.e. when $Y=0$ ). The reciprocal of the slope (b) of the straight line (i.e. $1 / b)$ is $(K)$, which is the number of degree-days (DDUs) above $\left(t_{0}\right)$ required by an animal to complete its development as physiological time (Sharpe and De Michele 1977).

\section{RESULTS AND DISCUSSION}

\section{Developmental times}

Obtained developmental times of various stages of $T$. urticae on Kostata and Hachiya persimmon varieties at four constant temperatures (i.e. 15, 20, 25 and $30 \pm$ $2{ }^{\circ} \mathrm{C}$ ), and $70 \pm 5 \% \mathrm{RH}$ are presented in Table (1). T. urticae females hatched after $13.83,9.07,5.27$, and 3.27 days at $15,20,25$ and $30^{\circ} \mathrm{C}$ on Kostata persimmon variety, respectively, while males hatched after shorter periods (Table1).

Developmental durations showed that females reached maturity after 37.9 and 12.2 days at 15 and $30^{\circ} \mathrm{C}$ on Kostata variety, while these values ranged between 30.1 and 11.15 days for males, respectively, on Hachiya variety. Developmental duration was shorter on Hachiya variety.

Longevity of females and males followed similar trend. Longevity was longer on Kostata variety than on Hachiya variety at four constant temperatures.

Farrage (1975) found that immature stages of T. arabicus lasted from 5.6 days in female and male at $27^{\circ} \mathrm{C}$ and 18.5 days at $13^{\circ} \mathrm{C}$. The female longevity varied from 11.9 to 24.5 days at 27 and $13^{\circ} \mathrm{C}$ respectively. Kim et. al. (1993) showed that, developmental periods of Tetranychus kanzawai Kishida, reared on flowing tea leaves, were studied at $15,20,25$ and $30^{\circ} \mathrm{C}$. The longest duration was found to be at $15^{\circ} \mathrm{C}$, the shortest at $30^{\circ} \mathrm{C}$. Adult female longevity was $33.3,16.8,15.5$ and 13.4 days, respectively. Another example Liu and Tsai (1998) studied the development of Tetranychus tumidus Banks on Coconut palm at 6 constant temperatures $(10,15$ ,20, 25,30 and $35^{\circ} \mathrm{C}$ ), the developmental periods of immature stages ranged from 39.6 days at $15^{\circ} \mathrm{C}$ to 7.4 days at $30^{\circ} \mathrm{C}$. While failed to develop beyond the larval stage at $10^{\circ} \mathrm{C}$. Abdel-wahed (2003) found the shortest developmental time of female and male of $T$. urticae were $8.31 \& 7.43$ days at $30^{\circ} \mathrm{C}$ when fed on Peach leaves. 


\section{Life table parameters of T.urticae}

Results in Table (2) showed that mean generation time $(T)$ decreased from 43.47 to 14.34 days and from 40.34 to 11.95 days at 15 and $30^{\circ} \mathrm{C}$ on Kostata and Hachiya varieties, respectively. The same trend was observed for other life table parameters (Table 2). The shortest time for population density doubling (DT) 2.85 and 2.33 days at $30^{\circ} \mathrm{C}$, while the longest period was 15.4 and 11.36 days at $15^{\circ} \mathrm{C}$ on Kostata and Hachiya varieties, respectively.

Temperature and variety affected the sex ratio (females/Total) of the mite. The proportion of females in offspring increased with temperature increase. The maximum values of intrinsic rate of increase $\left(\mathbf{r}_{\mathbf{m}}\right)$ and the finite rate of increase $(\boldsymbol{\lambda})$ was obtained at $30^{\circ} \mathrm{C}(0.243 \& 1.27$ and $0.297 \& 1.34$ individuals/ $/$ /day $)$ on Kostata and Hachiya varieties, respectively. Minimum values were obtained at $15^{\circ} \mathrm{C}$. The peak net reproductive rate (Ro) occurred at $30{ }^{\circ} \mathrm{C}$ as 47.51 and 63.47 individuals/ $\circ$ on Kostata and Hachiya varieties, respectively, the lowest was at $15{ }^{\circ} \mathrm{C}$, also the gross reproductive rate (GRR) was highest at $30{ }^{\circ} \mathrm{C}$ (63 and 99 eggs/o/generation) while the lowest was at $15^{\circ} \mathrm{C}$ (17 and 20 eggs/\%/generation), respectively.

The daily age-specific survival rate of female (Lx) and age-specific fecundity rate $\left(M_{x}\right)$ of $T$. urticae on Kostata variety was illustrated in Fig. (1) and on Hachiya in Fig. (2). The daily age-specific survival rate was highest at $15^{\circ} \mathrm{C}$ and decreased as the temperature increased on two persimmon varieties. The maximum number of eggs produced on Kostata variety was at $30^{\circ} \mathrm{C}$ (day $15: 8.93 \mathrm{egg} /$ / $/$ day), the lowest value was obtained at $15^{\circ} \mathrm{C}$ (day 44: $1.65 \mathrm{egg} /$ / $/$ day) on Kostata variety. The highest values obtained at $30^{\circ} \mathrm{C}$ (day 14: $11.02 \mathrm{egg} /$ / $/$ day), the lowest values obtained at $15^{\circ} \mathrm{C}$ ( day 40: $2.96 \mathrm{egg} / \mathrm{f} /$ day) on Hachiya variety, with daily egg production gradually decreased thereafter.

Heikal et. al. (1996) Showed that Black michen Fig variety harbored the greatest $T$. urticae ( $=T$. arabicus) density followed by Conadria variety, while Doritto was the least sensitive variety. Also, found that the three fig varieties significantly differed in their susceptibility giving, the highest fecundity 104.6 eggs/ + on Black michen, and the lowest 26.3 eggs/ 9 on Dorrito.

Bounfour and Tanigoshi (2001) stated that the net reproductive rate $\left(R_{0}\right)$ and the mean generation time $(T)$ of $T$. urticae were 24.66, 80.99, 54.86 and 86.01 and $38.29,26.48,21.25$ and 13.86 days when mite reared at $15,20,25$ and $30{ }^{\circ} \mathrm{C}$, respectively. Razmjou et. al., (2009) reported that $R_{0}$ and $T$ ranged between 12.57 and 30.51 and 10.66 and 11.66 days when reared $T$. urticae at $25^{\circ} \mathrm{C}$ on five bean cultivars, whereas, Osman et. al. (2010) showed that $\mathrm{R}_{0}$ and $\mathrm{T}$ of $T$. urticae were 36.98 and 16.19 at $28^{\circ} \mathrm{C}$. El- Halawany (2001) found that, the high fecundity of 
female $\left(128.05\right.$ eggs/ + ) was recorded at $30^{\circ} \mathrm{C}$. In addition, the highest intrinsic rate of increase $\left(r_{m}\right)(0.29)$ was obtained at $30^{\circ} \mathrm{C}$ when $T$. urticae fed on Black michen fig variety, and lowest fecundity 32.68 eggs/ 9 and the lowest $\left(r_{m}\right)(0.040)$ was obtained at $15^{\circ} \mathrm{C}$ on Gizi fig variety.

Abdel-wahed (2003) indicated that, the highest total mean fecundity was found at $30^{\circ} \mathrm{C}$ as 149.18 eggs/ $\circ$ at highest $r_{m} 0.24$, while the longest generation was obtained at $15^{\circ} \mathrm{C}$ as 38.96 days. Ismail, (2009) found the intrinsic rate of increase (rm) of $T$. urticae at $30,25,20$, and $15^{\circ} \mathrm{C}$ was $0.148,0.160,0.111$, and 0.042 $/$ / $/$ day, respectively. Riahi et al. (2011) indicated the intrinsic rates of increase $\left(r_{\mathrm{m}}\right)$ of $T$. urticae were $0.07,0.21$ and 0.18 , on three different peach varieties. Significant differences between Redtap and the other two varieties, concluding that the Redtap variety was not a suitable host as the other two varieties.

Osman et. al. (2012) found that, the mean generation time ( $T$ ) averaged $20.259,18.345,14.029,10.282$ and 8.775 days. The net reproductive rate $\left(R_{0}\right)$ values were $22.842,27.024,27.846,22.738$ and 9.790 when $T$. urticae was kept at the same temperatures. The intrinsic rate of natural increase $\left(r_{m}\right)$ was $0.1543,0.179,0.237$, 0.303 and 0.259 and the finite rate of increase (exp $r_{m}$ ) averaged 1.166, 1.196, 1.267, 1.355 and 1.296 at $15,20,25,30$ and $35^{\circ} \mathrm{C}$, respectively.

\section{Thermal requirements}

Results of applying the linear model to the relation between temperature and rate of development in insects and mites is usually calculated as linear (Sharpe and De Michele, 1977). Table (3) indicated that, $\mathbf{R}^{2}$ values of $T$. urticae ranged between 0.93 and 0.99 of egg, larva, Protonymph, Deutonymph, generation and life span on Kostata and Hachiya persimmon varieties, respectively. Using the equation resulted in determination of lower thresholds $\left(\mathbf{t}_{\mathbf{0}}\right)$ as $11.63 \& 11.17,5.55 \& 7.64,5.35 \& 6.63$, $8.32 \& 9.49,7.93 \& 9.25$ and $3.8 \& 5.57^{\circ} \mathrm{C}$. The thermal constant $(\mathbf{K})$ was $64.10 \&$ $68.02,78.12 \& 56.49,71.42 \& 61.34,54.34 \& 41.49,312.5 \& 256.4$ and $666.6 \&$ 526.3 DDs for the two previous Persimmon varieties as physiological times required for this species phenomena.

The simple linear regression between temperature $(\mathrm{X})$ and developmental rate (Y) of T. urticae (fig.3), the regression equation of egg, larva, protonymph, deutonymph, generation and life span were $Y=0.0156 x-0.1815, Y=0.0128 x-0.0711$, $Y=0.014 x-0.075, Y=0.0184 x-0.1531, Y=0.0032 x-0.0254$ and $Y=0.0015 x-0.0057$ on Kostata variety, respectively. In addition, the regression equation on Hachiya variety was near to the previous values.

These results agreed with those of Al-Sweedy (2003) who reared Oligonychus afrasiaticus (McGregor) at 15, 20, 25, 30 and $35^{\circ} \mathrm{C}$ on date palm. The thermal 
constant (K) for egg, larva, protonymph, deutonymph and life cycle was 63.34, $49.72,29.29,32.8$ and 172.17 DDus, respectively, the lower thresholds $\left(\mathbf{t}_{\mathbf{0}}\right)$ as 12.32 , $11,14.76,14.43$ and $13{ }^{\circ} \mathrm{C}$, respectively. Ismail (2009) studied the biology of Panonychus citri (McGregor) on sweet orange leaves were determined at 15, 20, 25, 30 and $35 \pm 1{ }^{\circ} \mathrm{C}, 65 \pm 10 \% \mathrm{RH}$, the development threshold for female eggs and immature stages was $9.22{ }^{\circ} \mathrm{C}$ and $9.77{ }^{\circ} \mathrm{C}$, respectively, while total effective temperature was 100 and 192.30 degree-days, respectively.

Osman et. al. (2012) studied $\mathrm{R}^{2}$ values of larva, protonymph, deutonymph, total immatures and life cycle of $T$. urticae on caster bean as well as were 0.9102 , $0.9232,0.9013,0.93880 .96$, regression equations.

As a result, it was noted that thermal factor had negative relationship with duration of each stage as increasing temperature rapped development and shortened, generation and life span of $T$. urticae.

Table 1. Mean developmental times in days of $T$. urticae females and males reared on Kostata and Hachiya persimmon varieties at constant temperatures and $70 \pm$ $5 \% \mathrm{RH}$.

\begin{tabular}{|c|c|c|c|c|c|c|c|c|c|}
\hline \multirow{2}{*}{ Parameter } & \multirow{2}{*}{ sex } & \multicolumn{4}{|c|}{ Kostata } & \multicolumn{4}{|c|}{ Hachiya } \\
\hline & & $15^{\circ} \mathrm{C}$ & $20^{\circ} \mathrm{C}$ & $25^{\circ} \mathrm{C}$ & $30^{\circ} \mathrm{C}$ & $15^{\circ} \mathrm{C}$ & $20^{\circ} \mathrm{C}$ & $25^{\circ} \mathrm{C}$ & $30^{\circ} \mathrm{C}$ \\
\hline \multirow{2}{*}{ Egg } & q & 13.83 & 9.07 & 5.27 & 3.27 & 13.73 & 9.3 & 5.12 & 3.47 \\
\hline & $\hat{o}$ & 13.15 & 8.7 & 5.05 & 3.35 & 13.5 & 9 & 5 & 3.4 \\
\hline \multirow{2}{*}{ Larva } & 우 & 9.27 & 5.2 & 3.65 & 3.4 & 8.62 & 4.25 & 3.2 & 2.6 \\
\hline & $\hat{0}$ & 8.55 & 4.45 & 3.45 & 2.95 & 8.05 & 4.15 & 2.5 & 2.15 \\
\hline \multirow{2}{*}{ Protonymph } & 우 & 7.32 & 5.27 & 3.35 & 3 & 6.85 & 4.5 & 3.85 & 2.47 \\
\hline & $\hat{0}$ & 6.85 & 4.7 & 2.95 & 2.6 & 6.55 & 4.45 & 2.6 & 2 \\
\hline \multirow{2}{*}{ Deutonymph } & q & 7.47 & 5.25 & 3.12 & 2.52 & 6.87 & 4.4 & 2.62 & 2.02 \\
\hline & $\hat{\sigma}$ & 6.65 & 4.65 & 3.05 & 2.25 & 6.6 & 4.3 & 2.1 & 1.7 \\
\hline \multirow{2}{*}{$\begin{array}{l}\text { Immature } \\
\text { stages }\end{array}$} & q & 24.08 & 15.73 & 10.13 & 8.92 & 22.35 & 13.15 & 9.67 & 7.1 \\
\hline & $\hat{\sigma}$ & 22.05 & 13.8 & 9.45 & 7.8 & 21.2 & 12.9 & 7.2 & 5.85 \\
\hline \multirow{2}{*}{ Life cycle } & 우 & 37.9 & 24.8 & 15.4 & 12.2 & 36.08 & 22.45 & 14.8 & 10.58 \\
\hline & $\hat{0}$ & 30.1 & 22.5 & 14.5 & 11.15 & 34.7 & 21.9 & 12.2 & 9.25 \\
\hline \multirow{2}{*}{ Longevity } & q & 20.58 & 16.23 & 15.45 & 12.98 & 18.58 & 15.35 & 13.6 & 10.85 \\
\hline & o & 19.8 & 14.45 & 12.7 & 11.8 & 17.8 & 13.2 & 10.55 & 9.3 \\
\hline \multirow{2}{*}{ Life span } & 우 & 58.48 & 41.03 & 30.85 & 25.18 & 54.65 & 37.8 & 28.4 & 21.43 \\
\hline & $\hat{0}$ & 49.9 & 36.95 & 27.2 & 22.95 & 52.5 & 35.1 & 22.75 & 18.55 \\
\hline
\end{tabular}


Table 2. Life table parameters of T. urticae under different temperatures.

\begin{tabular}{|c|c|c|c|c|c|c|c|c|}
\hline \multirow{2}{*}{ Parameter } & \multicolumn{4}{|c|}{ Kostata } & \multicolumn{4}{|c|}{ Hachiya } \\
\hline & $15^{\circ} \mathrm{C}$ & $20^{\circ} \mathrm{C}$ & $25^{\circ} \mathrm{C}$ & $30^{\circ} \mathrm{C}$ & $15^{\circ} \mathrm{C}$ & $20^{\circ} \mathrm{C}$ & $25^{\circ} \mathrm{C}$ & $30^{\circ} \mathrm{C}$ \\
\hline Generation time $(T)^{a}$ & 43.47 & 27.13 & 17.71 & 14.34 & 40.34 & 24.53 & 16.29 & 11.95 \\
\hline Preoviposition period ${ }^{\mathrm{a}}$ & 5.57 & 2.4 & 2.27 & 2.1 & 4.27 & 2.05 & 1.5 & 1.35 \\
\hline Oviposition period ${ }^{a}$ & 13.35 & 11.55 & 11.23 & 9.2 & 12.58 & 11.23 & 10.43 & 8 \\
\hline Mean total fecundity $(\mathrm{egg} / \&)$ & 26.55 & 42.55 & 69.1 & 78.6 & 38.8 & 56.6 & 79.7 & 96 \\
\hline Daily rate (egg/ + /day) & 2.04 & 3.77 & 6.32 & 8.81 & 3.15 & 5.13 & 8.02 & 12.62 \\
\hline Mean generation time $\left(T_{c}\right)^{a}$ & 44.24 & 30.03 & 19.97 & 15.85 & 41.86 & 27.28 & 18.96 & 13.94 \\
\hline Doubling time (DT) ${ }^{a}$ & 15.40 & 7.78 & 3.91 & 2.85 & 11.36 & 6.02 & 3.41 & 2.33 \\
\hline Net reproductive rate $\left(R_{0}\right)^{b}$ & 7.38 & 14.97 & 34.34 & 47.51 & 13.36 & 23.34 & 47.22 & 63.47 \\
\hline Intrinsic rate of increase $\left(r_{m}\right)^{c}$ & 0.045 & 0.089 & 0.177 & 0.243 & 0.061 & 0.115 & 0.203 & 0.297 \\
\hline Finite rate of increase $(\lambda)$ & 1.04 & 1.09 & 1.19 & 1.27 & 1.06 & 1.12 & 1.22 & 1.34 \\
\hline Sex ratio ( + /total) & 0.55 & 0.68 & 0.71 & 0.77 & 0.65 & 0.75 & 0.79 & 0.76 \\
\hline $50 \%$ mortality ${ }^{a}$ & 37.40 & 33.0 & 25.0 & 20.0 & 45.58 & 31.0 & 23.0 & 18.0 \\
\hline Gross reproduction rate (GRR) & 17 & 34 & 57 & 63 & 28 & 47 & 76 & 99 \\
\hline
\end{tabular}

${ }^{a}$ Days ${ }^{b}$ per generation ${ }^{c}$ Individuals/female/ day

Table 3. Linear regression analysis values for the effect of temperature on T. urticae developmental rate.

\begin{tabular}{|l|c|c|c|c|c|c|}
\hline stage & Variety & $\mathbf{a}$ & $\mathbf{b}$ & $\mathbf{t}_{\mathbf{0}}$ & $\mathrm{K}$ & $\mathbf{R}^{2}$ \\
\hline \multirow{3}{*}{ Egg } & Kostata & -0.1815 & 0.0156 & 11.63 & 64.10 & 0.95 \\
\cline { 2 - 6 } & Hachiya & -0.1643 & 0.0147 & 11.17 & 68.02 & 0.99 \\
\hline \multirow{3}{*}{ Larva } & Kostata & -0.0711 & 0.0128 & 5.55 & 78.12 & 0.94 \\
\cline { 2 - 7 } & Hachiya & -0.1353 & 0.0177 & 7.64 & 56.49 & 0.98 \\
\hline \multirow{3}{*}{ Protonymph } & Kostata & -0.075 & 0.014 & 5.35 & 71.42 & 0.96 \\
\cline { 2 - 7 } & Hachiya & -0.1082 & 0.0163 & 6.63 & 61.34 & 0.93 \\
\hline \multirow{2}{*}{ Generation } & Kostata & -0.1531 & 0.0184 & 8.32 & 54.34 & 0.97 \\
\cline { 2 - 7 } & Hachiya & -0.2289 & 0.0241 & 9.49 & 41.49 & 0.98 \\
\hline \multirow{2}{*}{ Life span } & Kostata & -0.0254 & 0.0032 & 7.93 & 312.5 & 0.99 \\
\cline { 2 - 7 } & Hachiya & -0.0361 & 0.0039 & 9.25 & 256.4 & 0.99 \\
\cline { 2 - 7 } & Kostata & -0.0057 & 0.0015 & 3.8 & 666.6 & 0.99 \\
\cline { 2 - 7 } & Hachiya & -0.0106 & 0.0019 & 5.57 & 526.3 & 0.99 \\
\hline
\end{tabular}

$\mathrm{a}=$ Intercept, $\mathrm{b}=$ slope of temperature, $\mathrm{t} 0=(-\mathrm{a} / \mathrm{b}) \quad \mathrm{K}=$ DDUs $(1 / \mathrm{b})$ 

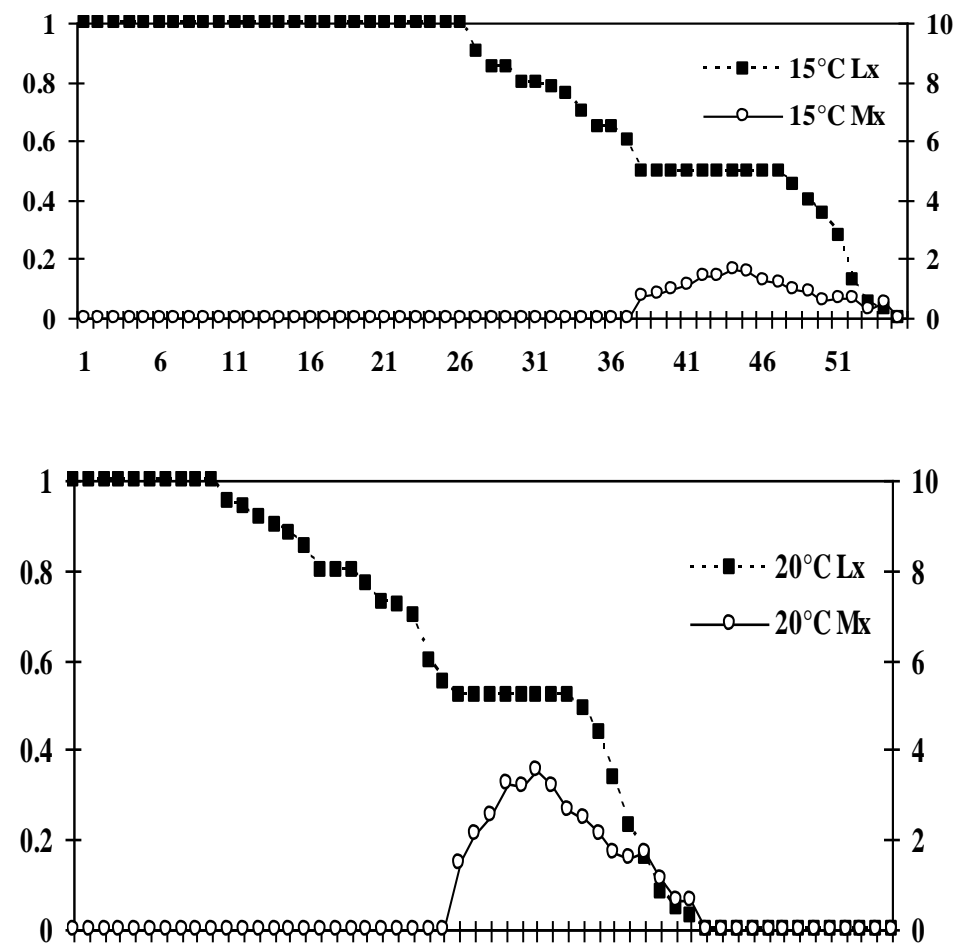

$\frac{\sqrt[x]{d}}{\sum_{0}^{n}}$
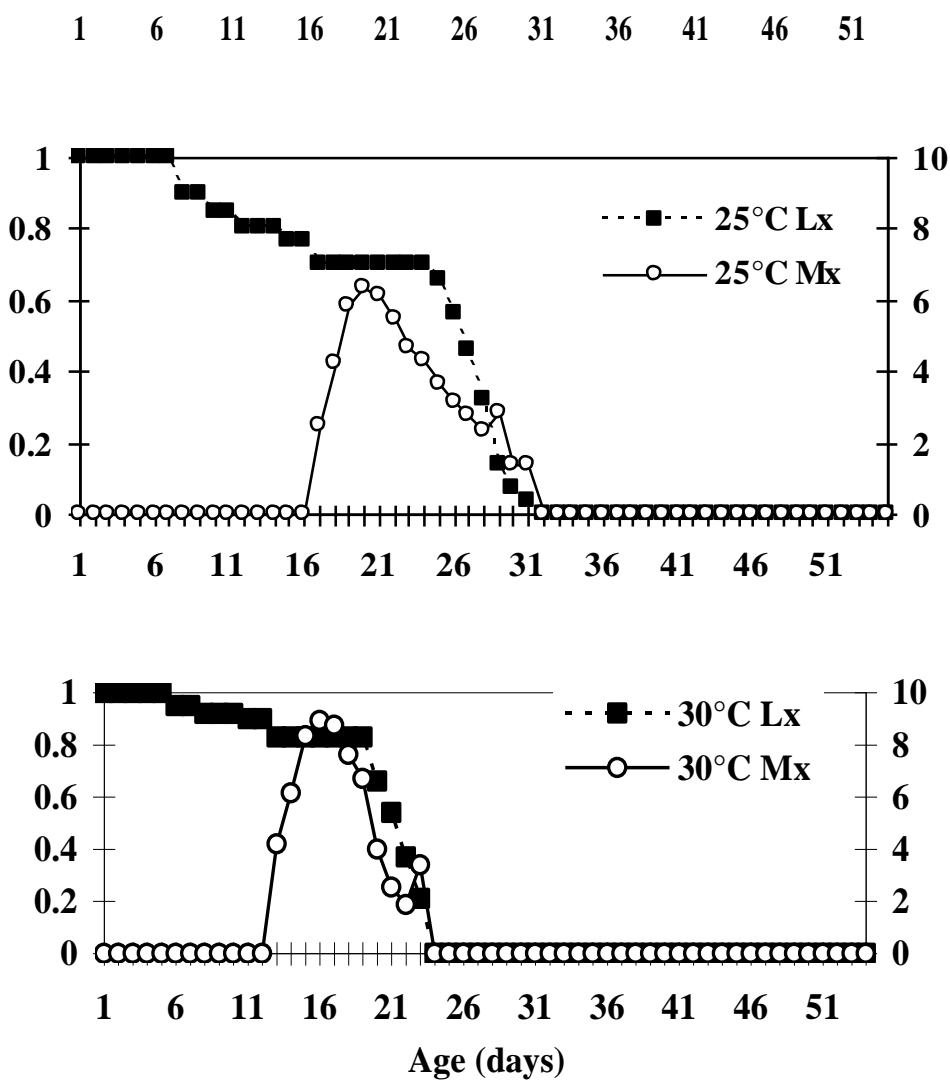

Fig. 1. Survival rate (Lx) and Age-specific rate fecundity (Mx) in $T$. urticae at different temperatures on Kostata Persimmon variety 


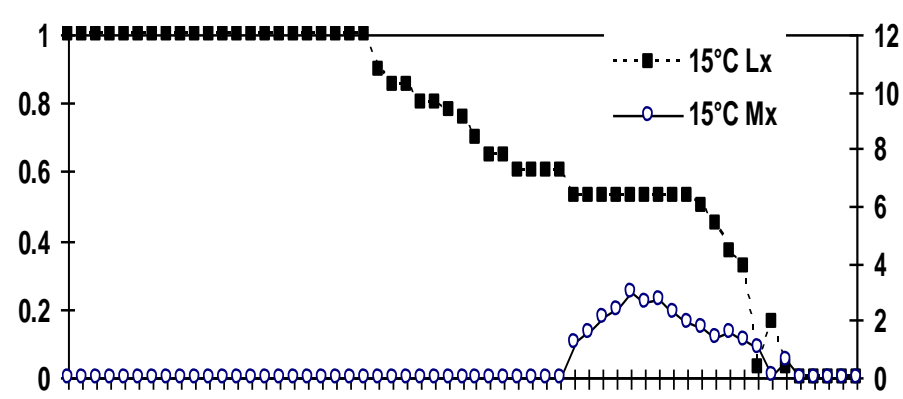

$\begin{array}{llllllllllll}1 & 6 & 11 & 16 & 21 & 26 & 31 & 36 & 41 & 46 & 51 & 56\end{array}$
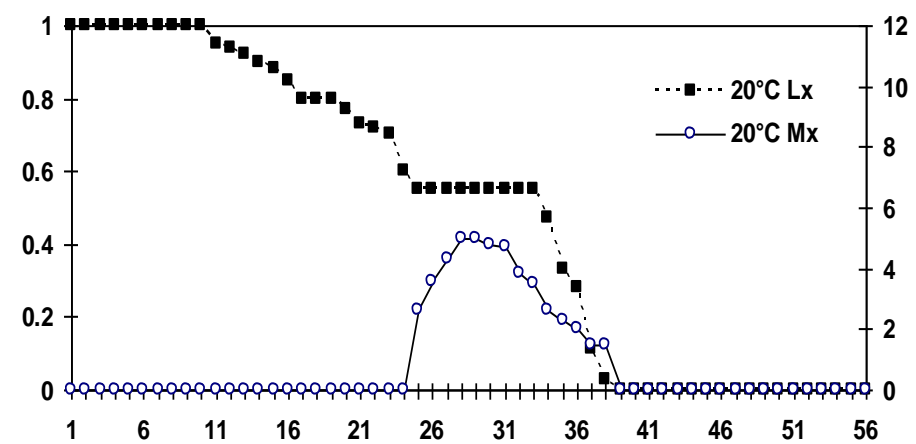

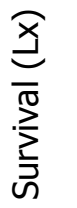
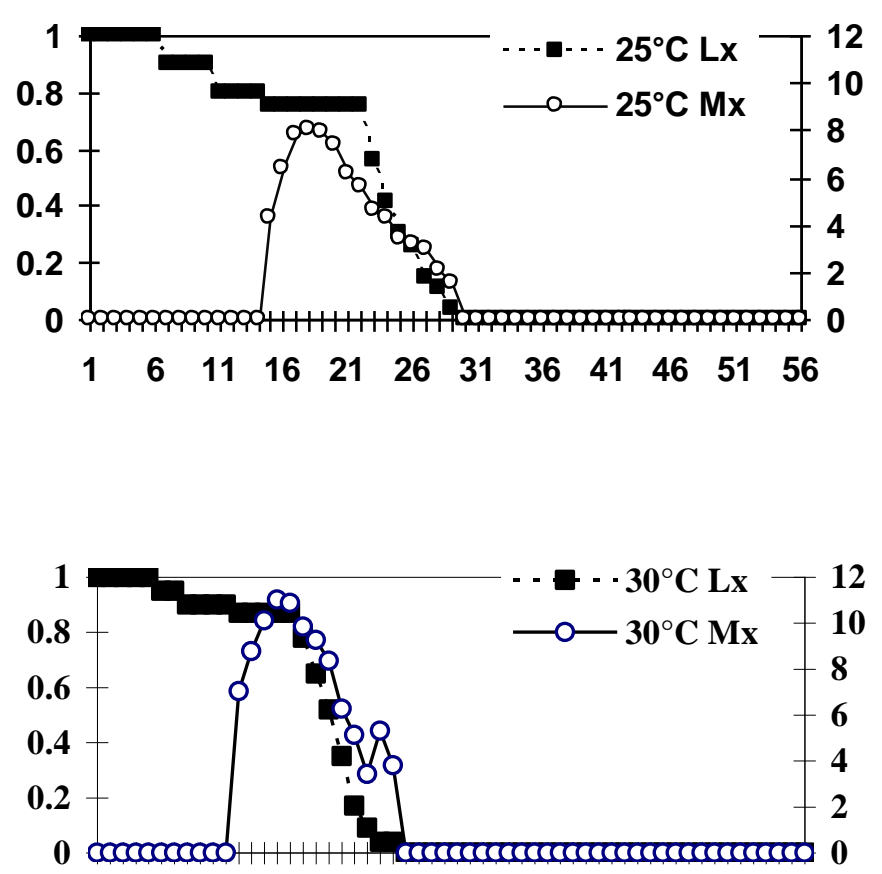

$\begin{array}{llllllllllll}1 & 6 & 11 & 16 & 21 & 26 & 31 & 36 & 41 & 46 & 51 & 56\end{array}$

Age (days)

Fig. 2. Survival rate (Lx) and Age-specific rate fecundity (Mx) in T. urticae at different temperatures on Hachiya Persimmon variety. 
EFFECT OF TEMPERATURE AND HOST PLANT ON DVELOPMENTAL TIMES AND LIFE TABLE PRARMETERS OF TETRANYCHUS URTICAE KOCH ON PERSIMMON TREES. (ACARI: TETRANYCHIDAE)

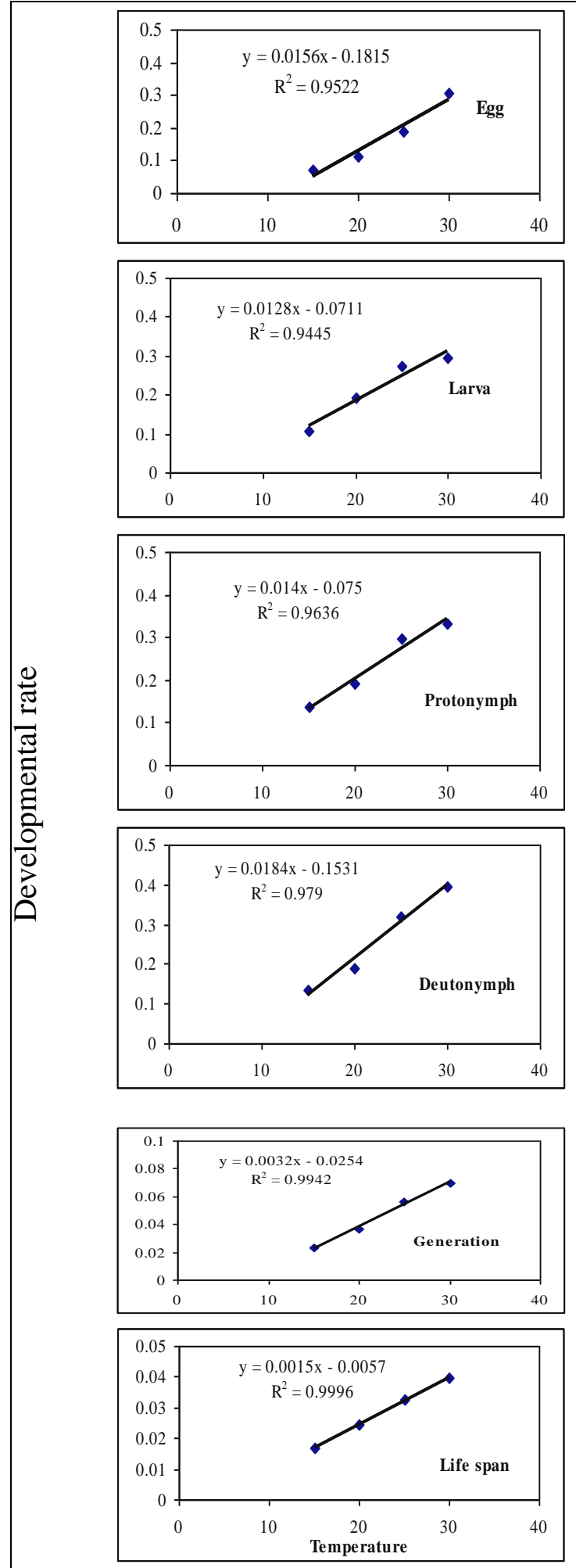

Kostata
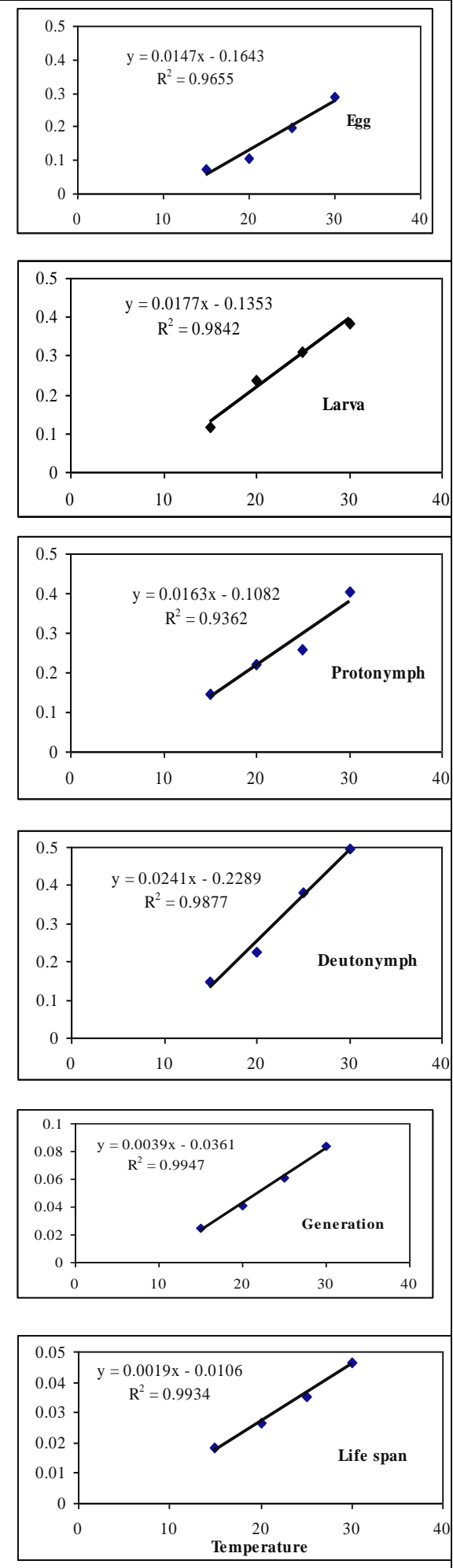

Hachiya

Fig. 3. Linear regression analysis values for the effect of temperature on T. urticae developmental rate. 


\section{REFERENCES}

1. Abdel-Wahed, N. M. 2003. Studies on some mites associated with certain fruit trees. Ph. D. Thesis, Fac. Agric., Al-Azhar Univ., 188pp.

2. Abou-Setta, M. M., Sorrell, R.W. and C.C. Childers. 1986. Life 48: a BASIC computer program to calculate life table parameters for an insect or mite species. Fla. Entomol. 69:690-697.

3. Al-Sweedy, T. M. 2003. Heat accumulation, fecundity schedules and life table structure of old world date mite (Ghobar mite) Oligonychus afrasiaticus (McGregor) (Acari: Tetranychidae). M.Sc. Thesis, College of Agric., Baghdad Univ., Iraq. 94 pp.

4. Birch, L. C. 1948. The intrinsic rate of natural increase of an insect population. J. Anim. Ecol., 17: $15-26$.

5. Bounfour, M. and L. K. Tanigoshi. 2001. Effect of temperature on development and demographic parameters of Tetranychus urticae and Eotetranychus carpini borealis (Acari: Tetranychidae). Ann. Entomol. Soc. Am. 94 (3):400-404

6. El-Halawany, A. S. 2001. Studies on some mite species infesting some fruit trees. M.Sc. Thesis, Fac. Agric., Zagazig Univ., Banha Branch. 164 pp.

7. Farrag, A.M., 1975. Biological and ecological studies on family Tetranychidae. Ph. D. Thesis, Fac. Agric. Zoo. Cairo Univ. 135pp.

8. Heikal, I. H., S. M. Ibrahim and N. G. Iskander. 1996. Ecological and biological studies on mite occurring on fig trees at Barrage District (Qalyobia Governorate), Egypt. J. Agric. Res., 74 (4): 919- 927.

9. Ismail, K. 2008. Life history of the brown mite, Bryobia rubrioculus Scheuten (Acari: Tetranychidae) on two apple varieties in laboratory conditions. Turk. Entomol. Derg. 32 (3): 177-184.

10. Ismail, K. 2009. The biology and fecundity of the citrus red mite, Panonychus citri (McGregor) (Acari: Tetranychidae) at different temperatures under laboratory conditions. Turk J. Agric., 33:593-600.

11. Kim, S. S., C. H. Paik, D.I. Kim, J.D. Park and S. C. Lee. 1993. Some ecological characteristics of tea red mite, Tetranychus kanzawai Kishida (Acarina: Tetranychidae). Korean J. Entomol., 23(4) 261-266.

12. Liu, Y. H. and J. H. Tsai. 1998. Development, survivorship and reproduction temperature. International. J. Acarol., 24 (3):245- 252. 
13. Osman, M. A., G. M. Abou Elella and A. A. Tawfik. 2010. Role of four-phytoseiid mite species and acarophagous ladybird, Stethorus gilvifrons (Mulsant) as bioagents of the two-spotted spider mite, Tetranychus urticae Koch. Acarines, 4: 47-55.

14. Osman, M. A., A. A. Tawfik, and G. M. Abou-Elella. 2012. The impact of temperature on Development and Demographic Parameters of Tetranychus urticae (Koch). Acarines, 6: 25-30.

15. Razmjou, J.; Vorburger, C., H. Tavakkoli and A. Fallahi. 2009. Comparative population growth parameters of the two-spotted spider mite, Tetranychus urticae Koch (Acari: Tetranychidae), on different common bean cultivars. Systematic \& Applied Acarology, 14: 83-90.

16. Riahi, E., A. Nemati, P. Shishehbor and Z. Saeidi. 2011. Population growth parameters of the two-spotted spider mite, Tetranychus urticae on three peach varieties in Iran. Acarologia 51(4): 473-480.

17. Sharpe, J. H. and D. W. De Michele. 1977. Reaction kinetics of poikilotherm development. J. Theor. Biol. 64: $649-670$.

18. Winston, P.W. and D. H. Bates. 1960. Saturated solutions for the control of humidity in biological research. Ecology 41(1): 232-236.

19. Zhang, Z. Q. 2003. Mites of greenhouse. Identifcation, biology and control. CABI Pub., 244 pp. 


\section{تأثير درجة الحرارة والعائل النباتي على فترة التطور وجداول الحياة للعنكبوت الأحمر العادي على أثجار الكاكى}

$$
\begin{aligned}
& \text { أشرف سعيد حجاج الحلو اني نزيه محمد عبد الواحد } \\
& \text { معرة بحوث وقاية النباتات - مركز البحوث النرراعية - الدقي - جيزة- مصر }
\end{aligned}
$$

• بعتبر العنكبوت الأحمر ذو البقعتين أحد أهم الآفات التي تصيب أثنجار الفاكهة الدتساقطة في مصر ، لذلك تم دراسة معدل البقاء و التكاثر وجدول الحياة للعنكبوت الأحمر العادي على العئ أثنجار

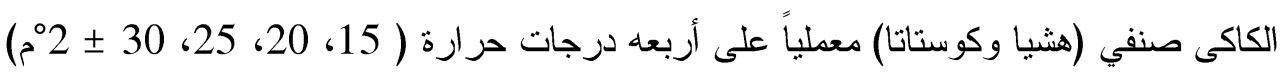
ورطوبة نسبية 70 × 5\%) وفترة إضاءة 16 ساعة.

• سجلت أقصر فترة لحضانة البيض وفترة الأطور غير الكاملة وفتزرة حياة الطور الكامل للإناث

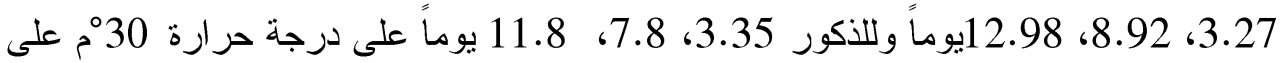
صنف كوستاتا على التو الي. • كان أعلى معدل للزيادة الطبيعي (rm) على درجة حرارة 30 مُ (0.243، 0.297 فرد/أنثى/

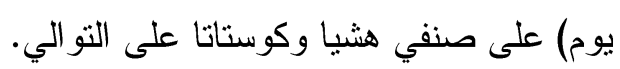

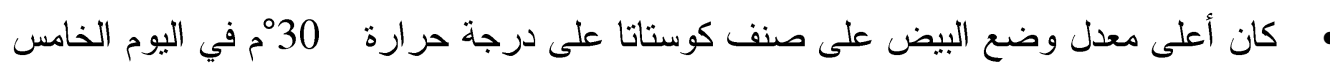

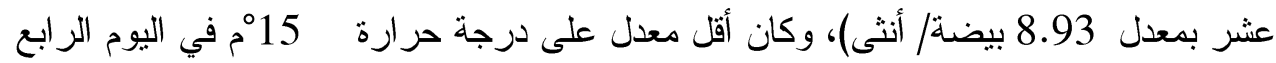

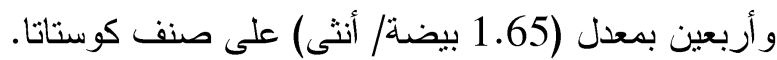

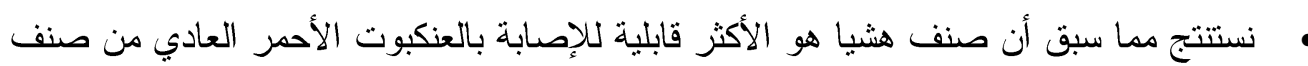

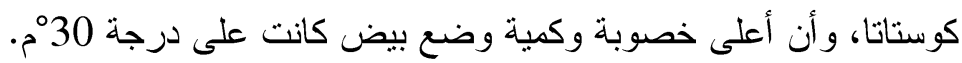

